addition, the building includes a library, the furniture for which was made in Messrs. Pilkington Brothers own carpentry and cabinet-making shops. The library already contains a nucleus of about 2,000 books, including a number of the earliest records of the firm dating from 1869. A number of striking examples of coloured glasses and fluorescent glass were shown in the laboratories. Both the exhibits and the equipment of the laboratories fully justified Sir William Bragg's remarks as to the national importance of the inauguration of this new research institution.

\title{
Fifth International Congress for Applied Mechanics
}

\begin{abstract}
$\mathrm{T}$ HE Fourth International Congress for Applied Mechanics was held at Cambridge, England, in 1934, and the Fifth very appropriately met at Cambridge, Massachusetts, on September 12-16. The Congress was attended by more than four hundred members as the guests of Harvard University and the Massachusetts Institute of Technology. More delightful hosts could not have been desired by the members who shared in the meetings and in the entertainments arranged by the local committee consisting of H. M. Westergaard, J. P. Den Hartog, J. C. Hunsaker, L. S. Marks and H. Peters.

The Congress was opened by Prof. K. T. Compton, president of the M.I.T., acting as president of the Congress. The work of the Congress was accomplished by means of technical sessions at which communications from members were read, by general lectures, and by a symposium on turbulence. The field of applied mechanies was divided into the following general heads : (I) Structures, elasticity, plasticity, fatigue, strength theory, crystal structure. (II) Hydro and aerodynamics, gas-dynamics, hydraulics, meteorology, water waves, heat transfer. (III) Dynamics of solids, vibration and sound, friction and lubrication, wear and seizure. Simultaneous sessions of the three sections were held. Abstracts of the papers presented were printed in English in the September issue of the Journal of Applied Mechanics, a copy of which was given to each member. Communications were received from the following workers from the British Empire : S. Brodetsky, L. P. Coombes, J. N. Goodier, A. A. Hall, C. E. Inglis, G. J. Klein, L. M. MilneThomson, E. F. Relf, F. G. Richardson, D. M. Smith, A. V. Stephens, J. L. Synge, and G. I. Taylor, who gave a general lecture on turbulence. The meetings were held at the M.I.T. for the first four days, and on the last day at Harvard University.
\end{abstract}

On Monday, September 12, members were able to be present at the dedication at the M.I.T. of the Wright Brothers Wind Tunnel, among the speakers at the opening ceremony being G. Brewer, of the Royal Aeronautical Society. The tunnel is a closed welded cylindrical steel circuit, with a 2,000 h.p. electric-motor and a variable pitch propeller, in which the air can be compressed to four atmospheres giving a Reynolds' number of $6,500,000$, or exhausted to one quarter of an atmosphere, when a velocity of 400 miles per hour is expected to be attained. The working section of this remarkable tunnel is an ellipse, ten feet by seven and a half feet.

Apart from attending lectures and hearing papors read, one of the great advantages of an international Congress is the opportunity of scientific workers from different countries meeting personally and exchanging ideas in a quite informal fashion. This opportunity was amply afforded by the receptions and conversaziones which were organized for each evening and contributed in no small measure to the success of the meetings. The largest social undertaking, apart from the final dinner, was the excursion on Thursday, September 15, to Middlesex School, the route passing through Lexington and Concord, places famous in American history. At the School a picnic supper was served, an address on Galileo's "Discorsi" was given by Dean S. H. Hollister, of Cornell University, and the proceedings were thereafter enlivened by a bonfire and a male chorus of Boston Negroes.

Following the Congress, members were invited to visit the National Bureau of Standards at Washington, D.C., and the aeronautical laboratory at Langley Field, Virginia. Many members availed themselves of this opportunity of seeing important scientific work in progress, and some very pleasant parts of the United States.

\section{New Laboratories of the Metropolitan Water Board}

WW Laboratories of the Metropolitan Water
Board were opened by the Minister of Health,
the Right Hon. Walter Elliot, M.P., on October 17
in the presence of a distinguished company. They
are situated at New River Head, Rosebery Avenue,
adjacent to the Boord's head offices, and replace
laboratories in Nottingham Place, which have been
in use since 1905.
The Metropolis Water Act of 1871 provided for
the appointment of a 'water examiner' by the Board
of Trade, and in early days the water supplied by the London water companies was subjected to daily examination by Sir William Crookes and Profs. James Dewar and Percy Frankland. Under the Metropolitan Water Act, 1902, by which the several existing water companies were consolidated into one undertaking under the newly constituted Metropolitan Water Board, the Board was similarly placed under an obligation to conduct chemical and bacteriological examinations of its water.

The Board in 1905 appointed the late Sir Alexander Houston to be "Director of Water Examinations"; 
he died in 1933 and was succeeded by the late Lieut.Colonel Harold. In 1936, the Board approved a scheme for the erection of new laboratories, and Colonel Harold and the appointed architect, Mr. Murray Easton, visited many laboratories in the United States in order to ascertain the latest developments in modern laboratory planning and practice. The present building is the outcome of their inquiries, but unfortunately Colonel Harold did not live to see its completion. A descriptive booklet has been issued in connexion with the opening, which contains views of the new building and of some of the laboratory interiors.

The new laboratory block has a north-south aspect and is built on a curved plan, the object of which was to allow more open space around, and to relate it to the existing head office block, so that in case of extension the quadrant would strike the end of that building. This construction not only produces a striking appearance architecturally, but also provides some thirty feet more space for the rooms facing north.

The basement contains store rooms, cold, cool biological, and spare laboratories, cold room and refrigerating plant, air conditioning plant, motors, centrifuge and boiler room, and workshop. The director's room is on the ground floor, with offices, library, photomicrographic room, biological, biochemical and bacteriological research laboratories. The first floor houses wash rooms for apparatus, preparation and sterilizing rooms for culture media, the bacteriological laboratory and sub-culture rooms, and four constant-temperature rooms for incubation. All the top floor accommodation faces north and is allotted to the chemical section, with rooms for distillation, balances, stills and fume cupboards.

The building is of brick with stone facings, and is steel framed. Rubber flooring is used for most of the laboratories, and laboratory benches are in teak. Vacuum and compressed air points are provided on the benches, also steam where required. Access to the various floors is provided by a lift and a circular staircase housed at the east end in a circular towerlike extension. Full details respecting construction, fittings and general lay-out are given in the booklet referred to above.

\section{University Events}

Вомвау.-Dr. K. Venkataraman, reader in dyeing and printing, has been appointed Mody professor and head of the Department of Chemical Technology in succession to Prof. R. B. Forster.

Cambridge.-The following appointments have recently been made: Dr. R. H. Thouless, of Corpus Christi College, University lecturer in education; Dr. J. T. Irving, of Gonville and Caius College, University lecturer in physiology; F. R. Berridge, of Trinity College, assistant in research in radiology (diagnostic); Dr. A. Paterson, of the University of Edinburgh, assistant in research in psychiatry.

The Research Committee of the Dyestuifs Group of Imperial Chemical Industries, Limited, has offered a research studentship to the University when the Company requires to encourage research of a particular subject. The stipend will be $£ 350$ for two years, with a possible extension, the appointment to be made by the University, after advertisement if desired.
A. R. H. Trim, of Trinity College, has been elected to the B. W. Levy studentship in biochemistry.

Dr. H. G. Sanders, University lecturer in agriculture, has been elected into a fellowship at St. John's College.

R. Howles, of St. John's College, has been appointed to the Frank Smart studentship in botany.

At Trinity College the following have been elected into fellowships: Dr. S. A. H. Rushton, Michael Foster student, 1925, Stokes student, 1927, Gedge prize, 1928, research fellow of Emmanuel College, 1930, University lecturer in physiology. D. J. Bauer, for research in physiology; Mr. Bauer gained a double first in the Natural Sciences Tripos and was Michael Foster student in 1937-38. E. R. Love, for research in mathematics; Mr. Love was a senjor optime in Part II of the Mathematical Tripos and gained honours, with distinction, in Part III; he was Smith's prizeman in 1937. W. C. Price, for research in physical chemistry.

The Managers give notice that an election to the Pinsent-Darwin studentship in mental pathology will be made in January 1939. The studentship is of the annual value of not less than $£ 225$ and is tenable for three years. The student must engage in original research into any problem having a bearing on mental defects, diseases or disorders, but may carry on educational or other work concurrently. Further information can be obtained from the Secretary, Pinsent-Darwin Studentship, Psychological Laboratory, Cambridge.

LONDON.-The appeal for an endowment fund of $£ 100,000$, which was launched a year ago on behalf of the Department of Business Administration, at the London School of Economics in the University of London, has not yet achieved its full objects. It had been hoped to raise a sum, the income from which would not only make the finances of the Department permanently secure, but would also enable it to carry out several much-needed developments. Further donations are urgently needed in order to achieve fully the purposes of the appeal. The amounts so far subscribed will nevertheless be sufficient to ensure the maintenance of the Department on its existing scale for a further period of seven years; and university students who contemplate a business career and wish to devote a post-graduate year to special training, may plan their studies in full confidence that the course will continue to offer at least the same facilities as hitherto.

SHEFrLLD.-The following appointments have recently been made : Dr. G. C. Hampson, assistant lecturer in chemistry; J. C. Colman, assistant lecturer in zoology; E. Baildon, assistant lecturer in mechanical engineering.

The Council has received a notification of a bequest, free from legacy duty, under the will of the late Mrs. Lucy H. Habershon, in the following terms : "To the University of Sheffield any of my late husband's books on mining or kindred subjects which they may care to have and the sum of Three thousand Pounds for the purpose of founding or establishing a fund to provide Scholarships in Mining to be called 'The Matthew Henry Habershon Scholarships', and a further sum of One thousand Pounds for coal dust research work."

Mr. M. H. Evans has resigned his post of lecturer in physics, and Dr. E. Seddon his post of lecturer in glass technology and research physicist. 